\title{
In memoriam: John W. Kendrick
}

\author{
C. A. Knox Lovell $\cdot$ Robin C. Sickles
}

Published online: 20 April 2010

(C) Springer Science+Business Media, LLC 2010

In 1994 John W. Kendrick delivered a plenary lecture to the Inaugural Georgia Productivity Workshop, precursor of the North American Productivity Workshop. The Workshop was held at the University of Georgia. At age 77 he was simply too busy to convert his lecture to an article for submission to the Journal of Productivity Analysis. Professor Kendrick stayed busy until he passed away November 172009 at the age of 92 .

Kendrick earned BA (history, Phi Beta Kappa) and MA (economics) degrees from the University of North Carolina at Chapel Hill, and a $\mathrm{PhD}$ (economics) degree from the George Washington University. Prior to earning his $\mathrm{PhD}$ Kendrick took up his first academic position, ironically at the University of Georgia, in 1939. Subsequently he worked for the National Resources Planning Board, served in the US Army Air Forces, worked for the Department of Commerce (the forerunner of the Bureau of Economic Analysis), and joined the staff of the National Bureau of Economic Research, where he worked for Solomon Fabricant. After earning his $\mathrm{PhD}$ Kendrick joined the economics department at GWU, where he remained until his ostensible retirement, when he became professor emeritus.

The 2010 Sixth Biennial North American Productivity Workshop, held at Rice University June 2-5, is dedicated to the memory of John W. Kendrick.

\section{A. K. Lovell}

University of Queensland, Brisbane, QLD, Australia

e-mail: k.lovell@uq.edu.au

C. A. K. Lovell

University of Georgia, Athens, GA, USA

R. C. Sickles $(\square)$

Rice University, Houston, TX, USA

e-mail: rsickles@rice.edu
If anyone deserves the appellation of father of productivity analysis, it is Kendrick. He had few predecessors, either analytically or empirically, although he paid particular homage to Fabricant and Hiram S. Davis, then at the Industrial Research Unit of the Wharton School of Finance and Commerce at the University of Pennsylvania.

In our brief discussion of Professor Kendrick's professional contributions we have chosen to focus on what we consider to be the two most significant of Professor Kendrick's many contributions to the field of productivity analysis.

Kendrick is best known for his monumental Productivity Trends in the United States (1961), and it is difficult to overstate the impact of this work. Kendrick prefaces a detailed empirical study of productivity from 1899 to 1957 with a discussion of the concepts and measurement of real output, real input and productivity. His empirical investigation reveals substantial variability in rates of productivity change through sub-periods and across sub-sectors of the total economy. He finds productivity growth to account for roughly half of output growth, and more than $80 \%$ of growth in output per unit of labor input, capital deepening accounting for the remainder. He also argues conceptually and demonstrates empirically that equality between national product and national income generates a dual measure of productivity change: the difference between the growth rate of output and the growth rate of input is equal to the difference between the growth rate of input prices and the growth rate of output prices. "[T]his is the means whereby the fruits of productivity gains are distributed to workers and investors by the market mechanism."

Kendrick also made important contributions to productivity measurement at the company level. His initial contribution, Measuring Company Productivity: Handbook with Case Studies (1961, with Daniel Creamer of the 
National Industrial Conference Board) was followed by Improving Company Productivity: Handbook with Case Studies (1984, in collaboration with the American Productivity Center). In these studies the focus shifts from productivity change in the total economy and its impact on national well-being to productivity change at a company and its impact on the financial well-being of the company. Kendrick expresses productivity change and its financial impacts both in conventional ratio form and in managerially oriented difference form. He applies aggregate practice to the company level by measuring "total factor" productivity change based on real value added, although he occasionally measures "total" productivity change based on real gross output. He achieves equality between nominal value added and nominal factor input by valuing capital at its gross rate of return. This practice does not equate real value added with real factor input, and the difference between the two represents the value of productivity change, the productivity bonus to be distributed among various claimants. Several case studies implement the procedures and illustrate alternative uses to which the procedures can be put. All case studies emphasize the measurement of capital and its gross rate of return. One case study compares total factor productivity and total productivity, thereby expressing what we now call the "Domar factor" in both ratio and value terms. Another case study extends the dual productivity index concept in difference format: the (primal) productivity bonus is fully distributed, to customers (as a price reduction) and to individual input suppliers (by means of input price increases).

Not only was Professor Kendrick a scholar of the first rank, whose contributions to the field of productivity compare to those of Edward Denison, Dale Jorgenson and Zvi Griliches, but he was a wonderful colleague and mentor. One of us (Sickles) had the remarkable fortune to have been a colleague of John Kendrick at George Washington University (not to mention being mentored as a graduate student by Knox Lovell and Peter Schmidt at UNC-Chapel Hill!). John was a warm and thoughtful senior colleague who was giving of his time and professional insights. His influence to generations of scholars and practitioners is profound. His legacy is not only a professional one, however, but for us, a very personal one.

He will be missed. 